\title{
A study of the Extent and Nature of Classroom Verbal Interaction in Tenth-Grade, Arabic Language Class in Jordan Using Flanders Interaction Analysis Category System (FIACS)
}

\author{
Hasan A. Al-Hasanat (Corresponding author) \\ Curriculum and Instruction Department \\ Al-Hussein Bin Talal University \\ Ma'an, Jordan \\ E-mail: hasanhasanat@yahoo.com \\ Rima A. Abu Omar \& Sami F. Aljazi \\ Curriculum and Instruction Department \\ Al-Hussein Bin Talal University \\ Ma'an, Jordan
}

Received: November 5, 2017 Accepted: December 2, 2017 Published: December 6, 2017

doi:10.5296/ijld.v7i4.12106

URL: https://doi.org/10.5296/ijld.v7i4.12106

\begin{abstract}
The purpose of the study was to examine the extent and nature of classroom verbal interaction in tenth-grade, Arabic language class using Flanders Interaction Analysis Category System (FIACS). In addition, the study examined extent and nature of classroom verbal interaction in this class based on teachers' gender, academic degree, and years of experience. The study sample consisted of 63 teachers who were teaching Arabic language for tenth grade in a group of schools in Ma'an governorate in Jordan. The used data collections tool was an observation sheet that developed based on FIACS for classroom observation.

The results revealed that the most common form of classroom verbal interaction was "teacher talk". The "direct influence" component of teacher talk was the dominant form of teacher talk with a rate of $40 \%$. The least common form of classroom verbal interaction was "silence or
\end{abstract}




\section{Macrothink}

International Journal of Learning and Development

ISSN 2164-4063 2017, Vol. 7, No. 4

confusion" with a rate of $0.07 \%$. Furthermore, the results showed that there were no significant differences $(\alpha=.05)$ in extent and nature of classroom verbal interaction based on teachers' gender and academic degree. However, there were significant differences $(\alpha=.05)$ in extent and nature of classroom verbal interaction based on teacher' years of experience.

Based on the findings, the study provided a set of recommendations. There is a need to improve classroom verbal interaction through encouraging teachers to initiate conversation with their students, encouraging students to participate in classroom events and discussion, and encouraging students to express and share their ideas and opinions during the class. The study recommended that there is a need to conduct more similar studies in other grades rather than tenth grade and in other subjects rather than Arabic language.

Keywords: classroom verbal interaction, Arabic language, flander's interaction analysis 


\section{Introduction}

Classroom verbal interaction; in form of discussion, dialogue, presenting ideas and exchanging of opinions; is a miniature form of real life experience. Improving classroom interaction has become a challenge and ambition for educators and teachers. Societies are looking to schools to adopt more practical educational goals to meet their needs in terms of improving students' academic performance, enhancing students' educational and psychological health, and improving students' positive attitudes towards their communities and towards themselves. Improving classroom interaction can be one of the ways to achieve these goals.

Educational literature asserted that the teaching process is one component of the educational curriculum. The literature emphasized on the need to conduct training for school teachers in order to make them acquire the proper teaching competencies. However, such training should focus on all components of effective teaching and its mutual relations with the elements of the educational curriculum. Such training should focus on how to enhance and improve the relationship and interaction between the teacher and the students (Shubar, Jamil, \& Abu-Zeid, 2005).

Classroom verbal interaction has received great attention from the educators. Classroom verbal interaction is an important component of the educational learning process for several reasons that include: strengthening the social relations between the teachers and their students, promoting the exchange of ideas and feelings between teacher and students and among students, and helping the teacher achieving the desired educational goals through effective communication between the teachers and the students as well as among the students themselves (Al-Badri, 2005).

Researchers in the cognitive psychology focused on the importance of classroom verbal interaction. One of the most common techniques to assess classroom verbal interaction is FIACS (Amidon \& Flanders, 1963). FIACS technique is one of the most noticeable and widespread observation technique used in observing the teaching process and in conducting educational research and teacher training.

FIACS technique is used to identify classroom practice i.e., verbal interaction. Educators believed that verbal interaction can be measured, recorded and controlled. Measuring verbal interaction provide teachers with better understanding of their classroom practices and help them acquire detailed visual presentation of their classroom activities. Measuring verbal interaction make the teachers aware of the characteristics of their classroom educational practice. Knowing characteristics of the teachers' classroom educational practice would train them to objectively understand their performance and to build a conscious plan in case of adopting the idea that the students should be active practitioners in the educational process and the idea that modern teacher is an indirect teacher (Al-Sfasfh, 2005).

Analyzing FIACS technique shows that the teacher should start his/her lesson with providing the students with a brief introduction related to the class topic, and some instructions and guidance related to the class management. Then, the teacher should provide the students with 
the main objectives of the lesson. After that, the teacher should ask the students questions, initiate discussion and provide explanations. Students' response to the questions and their ideas in the discussion should be accepted by the teacher. During the lesson, the teacher should praise the students' ideas, encourage them to participate in the classroom discussion and provide them with positive feedbacks. The teacher should work to accomplish the lesson's objectives in a friendly educational environment avoiding the moments of chaos as possible. During the lesson, the teacher should use different positive patterns of classroom verbal interaction.

The purpose of present study was to examine the extent and nature of classroom verbal interaction in tenth-grade Arabic language class in Ma'an Governorate in Jordan using FIACS. In addition, the study examined extent and nature of classroom verbal interaction in this class based on teachers' gender, academic degree, and years of experience.

\section{Theoretical Framework and Previous Studies}

\subsection{Theoretical Framework}

Teacher-student classroom interaction is important in the process of teaching and learning. The extent and quality of such interactions determines the effectiveness of the educational situation, the nature of the educational trends, and some of the characteristics of the educational environment. The management of classroom should not be limited to applying the rules and regulations and supervising the students in the educational environments, where more important than this is the management of teacher-student interaction. Such interaction includes accepting students' ideas and exchanging experiences (Qatami \& Qatami, 2001). Promoting positive teacher-student interaction would ensure that the students and the teachers are constantly active practitioners in the educational process. Promoting positive teacher-student interactions require establishing healthy social relationships between the teacher and students and limiting the role of the teacher to be organizer of the educational activities and helper to the students to take decisions rather than the controller of the educational process. Classroom interaction can be defined as an internal state that drives the individual to be awake and paying attention and to carry out ongoing activities that achieve learning (Adas, 1999).

Arifaj (2007) pointed out that mastering verbal and nonverbal communication skills, both direct and indirect, was essential for teachers' success in educational process. However, for successful classroom interaction, the teachers need to take into account several considerations that related to the general classroom environment, self-discipline according to the rules of the classroom, the learning objectives, the diversification of educational activities, and the adopted educational strategies. Arifaj (2007) pointed out that proper educational strategies should consider set of principles that include the following:

1. Defining the educational objectives, helping students to adopt these objectives as goals for their learning, and motivating the students to achieve these educational objectives.

2. Adopting educational strategies in which the students have clear and active roles in the learning process along with the role of teachers. Examples of such strategies include dialogue 
and discussion.

3. Providing feedbacks for students and activating incentive system.

4. Increasing the opportunities for inductive and deductive reasoning, analytical thinking, critical thinking, divergent thinking, inventive thinking, and creative thinking.

5. Supporting individual initiatives and creating opportunities for exploration and discovery.

6. Taking into account the diversity and variation of the students' preferences desires, abilities, and aptitudes.

The study and the analysis of teacher-student classroom verbal interaction helps to identify the teacher's success in providing a proper social environment that leads to better learning and achievements of educational goals. Teacher-student classroom verbal interaction can be recorded using recording devices e.g., video camera, or using special observation sheet. One of the most common techniques to assess classroom verbal interaction is FIACS (Amidon \& Flanders, 1963). Regarding FIACS, Amatari (2015) stated that:

Interaction Analysis is a technique for capturing quantitative and qualitative dimensions of teacher verbal behaviour in the classroom. As an observational system, it captures the verbal behaviour of teachers and students that is directly related to the social - emotional climate of the classroom. It was developed by Ned Flanders out of Social Psychological Theory and was designed to test the effect of social emotional climate on students' attitudes and learning. The theoretical assumptions of Interaction Analysis (IA) are that in a normal classroom situation, verbal communication is predominant; the teacher exerts a great deal of influence on the student and the student's behaviour is affected to a great extent y this type of teacher behaviour exhibited. (p.43)

According to Flanders (Amidon \& Flanders, 1963), this system measures the verbal part of classroom activities. Amatari, (2015) reported that 68 percent of teacher tasks within the classroom are verbal. Based on FIACS, there three major types of classroom events: 1) Teacher talk, (2) Student talk, (3) Silence or confusion. There are two types of teacher talk: indirect influence and direct influence. In teacher's indirect talk the students have the freedom to express their feelings and opinions. In teacher's direct talk the students have limited opportunities to express their feelings and opinions. There are two types of student s talk: response and initiation, where the student either responds to a question posed by the teacher or initiates an idea or question. Finally, classroom verbal interaction includes time spent in confusion and chaos in which the communication is interrupted and then the state of silence occurs. Table 1 shows a summary of FIACS (Amidon \& Flanders, 1963, p.12). 
Table 1. Summary of FIACS

1. Accepts feeling: accepts and clarifies the feeling tone of the students in a nonthreatening manner. Feelings may be positive or negative. Predicting and recalling feelings are included.

Indirect

Influence

2. Praises or encourages: praises or encourages student action or behavior. Jokes that release tension, not at the expense of another individual, nodding head or saying "uhhuh?" or "go on" are included.

3. Accepts or uses ideas of student: clarifying, building, or developing ideas or suggestions by a student. As teacher brings more of his own ideas into play, shift to category five.

Teacher

Talk

4. Asks questions: asking a question about content or procedure with the intent that a student answer.

5. Lecturing: giving facts or opinions about content or procedure; expressing his own idea; asking rhetorical questions.

Direct

Influence

6. Giving directions: directions, commands, or orders-with which a student is expected to comply.

7. Criticizing or justifying authority: statements intended to change student behavior from non acceptable to acceptable pattern; bawling someone out; stating why the teacher is doing what he is doing; extreme self reference.

8. Student talk-response: talk by students in response to teacher. Teacher initiates the contact or solicits student statement.

Student

Talk
9. Student talk-initiation: talk by students, which they initiate. If "calling on" student is only to indicate who may talk next, observer must decide student wanted to talk. If he did, use this category

10. Silence or confusion: pauses, short periods of silence, and periods of confusion in which communication cannot be understood by the observer.

Qatami and Qatami, (2001) reported that the results of research studies, that used FIACS, showed that encouraging teachers to adopt proper classroom verbal behaviors would enhance the classroom educational process. These results showed that the teachers, who received training related to classroom verbal interaction, had used effective instructional methods, where these teachers had been encouraging students' initiative and accepting students' ideas and building new ideas based on students' ideas. In addition, the students in the classes in which the teachers adopted indirect verbal interaction had significantly better performance and express more positive views than the students in the classes in which the teachers adopted direct verbal interaction. The following section discuses some related previous studies related to classroom verbal interaction.

\subsection{Previous Studies}

Several research studies have been conducted that examined the characteristics of classroom verbal interaction using FIACS. For instance, Ibrahim (1987) conducted a study aimed to identify and evaluate the prevalent patterns of teacher-student classroom verbal interaction in Arabic language class. The study aimed to identify the strength and weakness aspects of teacher-student interaction and to provide suggestions that can be made to develop teachers' performance. The study sample consisted of a number of teachers of Arabic language for the intermediate stage in the Taif schools in Saudi Arabia. The researcher used FIACS to examine 
the verbal interaction. The results showed the most dominant verbal interaction types were direct influence component of teacher talk and silence during the class time. In addition, there was noticeable low percentage of initiation component of student talk.

In another study, Al-Farra (2004) conducted a study that examined the levels of teacher-student classroom verbal interaction in Palestinian schools. The study sample consisted of 40 teachers from variety of disciplines in the primary stage in the governorates of Khan Younis and Rafah in the Gaza Strip. Different tools were used to assess the teacher-student classroom verbal interaction. These tools were developed by different researchers. The results of the study showed that the levels of interaction between the teachers and their students were positive and high, mainly when the teachers ask questions in the knowledge level. In addition, the results showed high level of praise and reinforcement pattern from teachers to students. Such high level of praise and reinforcement pattern might be attributed to the teachers' behaviors of providing in-classroom feedbacks for students regarding their assignments. In addition, the results showed high proportion of teacher talk during the classroom was in forms of "giving directions" and "criticism of students" behaviors".

Al-Hadi (2009) examined the patterns of prevalent teacher-student verbal interaction in the primary education in the Ouargla Province in Algeria. In addition, the study examined the differences in the level of interaction based on teachers' gender, academic degree, years of experience, and study levels for their students. The study sample consisted of 607 teachers from eleven districts. The researcher used FIACS to measure the verbal interaction patterns. The results showed that the teacher talked more than the students in the classroom. There were statistically significant differences in the extent of verbal interaction based on teachers' years of experience, where the teacher with relatively higher number of years of experience had a lower percentage of direct influence component of teacher talk and time of silence and high percentage of indirect influence teacher talk compared with teacher with relatively lower number of years of experience. There were no statistically significant differences in the extent of verbal interaction based on teachers' gender. However, there were statistically significant differences in the extent of verbal interaction based on the study levels for students.

In another study, Nurmasitah (2010) examined the characteristics of classroom verbal interaction in a Geography class. The study sample consisted of 30 students and one teacher in a special program for the intermediate and secondary school stages in Samarang, Indonesia. The researcher used FIACS to analyze the patterns of interaction prevailing in the classroom. The results of the study showed that most of the time classroom educational process was devoted for teacher's questions and lectures with 57.43\% rating, while the rate of student talk was $22.20 \%$. In addition, the results showed that students were fairly active in the classroom verbal interaction. The classroom verbal interaction was in different forms, between the teacher and the students and among students.

Gorongo (2013) used as case study approach to examine the nature of classroom verbal interaction in primary grades. The study sample consisted of 30 students, in which the number of male students was equal to the number of female students. The results showed that 
the percentage of teacher talk was higher than the percentage student talk; this meant that the verbal interaction in the class was dominated by the teachers, where students talk accounted of $33 \%$ of the of the time of interaction. Even the educators agreed that students learn more through active participation on the educational process; they rarely allowed high level of participations for the students in the classroom.

Al-Amiri (2016) analyzed classroom verbal interaction in which the study sample were group of student teachers in the department of social studies at the institution of preparation and training of teachers in service in Hadramout a city in the Republic of Yemen. The sample consisted of 35 male and female students. The researcher used FIACS in form of an observation sheet to measure classroom verbal interaction. After conducting the necessary statistical analysis, the results indicated that the proportion of direct influence component of teacher talk was high, while that the proportion of indirect influence component of teacher talk and the proportion of students' initiative pattern were low.

Sharma (2016) explored the properties of the classroom verbal interaction in math using FIACS. The study sample consisted of two groups of students in ninth grade in urban and rural schools in Punjab. The results showed that the foremost characteristics of classroom interaction in urban schools were explanation, student response to teacher questions, and students' initiative to ask questions or ideas. The results reflected that students in urban schools were more aware and involved in the discussion compared with students in rural areas. The results indicated that there was a high percentage of student talk in the urban schools sample, where the classroom environment in the in the urban schools was rich in discussion and participation in a democratic environment.

In light of the relevant studies, it is clear that the issue of classroom verbal interaction has captured a global intention in research and educational studies, while this topic has not received the same attention from Arab researchers. Furthermore, the previous studies showed that FIACS was common technique to assess the characteristics of classroom verbal interaction. In addition, the results of the previous studies showed that there were mixed results regarding the nature and quality of classroom verbal interaction. However, some these studies showed the direct influence component of teacher talk is the most dominant pattern of classroom verbal interaction.

Based on the researchers' best knowledge, there is only one study (Ibrahim, 1987) that examined the nature of classroom verbal interaction in Arabic language class. In addition, there was no one study that examined the nature of classroom verbal interaction in Arabic language class of tenth grade in Jordan. Such lack of studies would justify the need and the importance of the current study, where the current study is unique in the field of classroom interaction. It is expected that the results of this study would set the basis for researchers to conduct further studies that would examine the extent and nature of classroom verbal interaction among the Arabic class of different grades using FIACS and the relationship between the extent of verbal interaction and other factors that were not discussed in the present study. 


\section{Purpose of the Study}

Teaching has been viewed as an interactive process between teacher and their students. The verbal interaction plays an integral role in such process. Teacher controls the educational process in the classroom. Therefore, the teacher' behaviors in the classroom affect the nature of the verbal interaction between him/her and the learners.

Most of the classroom interaction is verbal interaction between the teacher and his/her students. The verbal interaction between the teacher and his/her students represent $70 \%$ of the teacher's tasks during the educational situation (Al-Sfasfh, 2005). It is crucial for the educators to look at, monitor, and know the amount or proportion of each party's (i.e., teacher and students) involvement in verbal interaction. Several studies (Ibrahim, 1987; Gorongo, 2013; Al-amiri, 2016) pointed that the teachers are dominant in the verbal interaction process in the classroom. Teachers' domination in the classroom verbal interaction would entrench their role as the controller of the educational process and make their teaching style depends on indoctrination, explanation and giving instructions. Such teaching style would allow less space for students to express their views and to participate in classroom discussion.

Based on the researchers' work experience in the Jordanian ministry of education, their experience as faculty members in the college of education at a university in Jordan, and their experience in supervising university students in their practicum at schools; they found that there was deficiency in the verbal communication between the teachers and their students. Furthermore, reviewing the theoretical literature and previous studies showed that there was scarcity in the studies that examined the classroom verbal interactions in Arab world in general and in Jordan in particular. Only one study (Ibrahim, 1987), was found, that examine classroom verbal interaction in Arabic language class. However, such study was relatively old one.

Hence, this study was conducted to examine the extent and nature of classroom verbal interaction in tenth-grade Arabic language class in Ma'an Governorate in Jordan using FIACS. In addition, the study examined extent and nature of classroom verbal interaction in this class based on teachers' gender, academic degree, and years of experience.

Specifically, the study attempted to answer the following questions:

1. What are the most common classroom verbal interaction patterns in Arabic language class of the tenth grade based on FIACS?

2. Are there statistically significant differences, at the level of $(\alpha=0.05)$, in the extent of teacher-student verbal interaction based on teachers' gender?

3. Are there statistically significant differences, at the level of $(\alpha=0.05)$, in the extent of teacher-student verbal interaction based on teachers' academic degree?

4. Are there statistically significant differences, at the level of $(\alpha=0.05)$, in the extent of teacher-student verbal interaction based on teachers' years of experience? 


\subsection{Importance of the Study}

The importance of this study was related to its contribution to the body knowledge in relation to the teacher-student verbal interactions. Based on the findings of the current study, recommendations for practice were provided. The findings of the present study might attract the attentions of decision makers and officials, who are responsible on teachers' training programs in the Jordan ministry of education, regarding the importance of teacher-student verbal interactions and the importance of encouraging the students to participate and to be initiative in classroom discussion, to ask questions, to show their ideas, and to highlight their innovations. Enhancing students' classroom participation would refine their personality, make them active student, make them active participants in decision-making, make them open-minded and self-confident, and facilitate freedom of expression. In addition, the findings of the current study might guide the design and implementation of teachers' training programs that aim to enhance teacher-student verbal interaction.

The importance of the study stems from the use of FIACS to assess the extent of teacher-student verbal interaction Arabic language for tenth grade teachers. FIACS can be used to evaluate the effectiveness of the training programs that aims to develop the classroom teacher-student verbal and cognitive interaction.

Based on the knowledge of the researchers, there is scarcity in the studies that dealt with the degree of verbal interaction in Arab world. The present study represents the second study that examined verbal interaction patterns in Arabic language class. The present study is the only study that select tenth grade teachers as sample of study to examine the classroom verbal interaction patterns through the use of FIACS. Therefore, the present study is one of an up-to-date study that may fill part of the research gap in the classroom verbal interaction area.

\subsection{Limitations of the Study}

This study was conducted within the following spatial, temporal and methodological limitations:

- The study took place in the public schools in only one governorate in Jordan that was Ma'an.

- Only students in tenth grade participated in the present study.

- The study was conducted in the second semester of the academic year 2016/2017.

- Only Arabic language teachers participated in the present study.

- The study took place in the Arabic language class for the tenth grade.

\subsection{Study Terms and Their Operational Definitions}

The following operational definitions of the used terms were adopted:

- Classroom verbal interaction: Al-Khatibeh, Al-Sultani and Al-Tuwaisi, (2004) reported that classroom verbal interaction can be defined as the extent of contact between the teacher and his/her students in the educational situations and among the 


\section{Macrothink Institute ${ }^{\text {TM }}$}

students themselves, where there is a need to provide appropriate and encouraging environment and activities to promote and maintain such interaction in the classroom. The adopted operational definition of classroom verbal interaction was the score on the scale of verbal interaction that include patterns of crosstalk and conversation between the teacher and the students within the classroom environment. The used scale was based on FIACS.

- Flanders Interaction Analysis Categories System (FIACS): "is a ten category system of communication which are said to be inclusive of all communication possibilities. There are seven categories used when the teacher is talking (Teacher talk) and two when the pupil is talking (Pupil talk) and tenth category is that of silence or confusion" (Amatari, 2015, p.44). The adopted operational definition of Flanders Interaction Analysis Categories System (FIACS) was an observation sheet that measure ten categories of classroom verbal interaction that were developed based on Flanders interaction analysis.

- The tenth grade: is the final grade of the upper elementary stage, where students study their subjects on two semesters in an academic year according to the educational system followed by the Jordanian ministry of education. The Arabic language course has two subjects: poetic / prose text and grammar.

- The Arabic language course: is a course that is taught to the tenth grade in Jordan. It consists of two parts with fourteen units. The students take the first seven units in the first semester and the other seven units in the second semester.

\section{Methodology of the Study}

\subsection{Study Population and Sample}

The study population consisted from all the male and female teachers of Arabic language for the tenth grade in Ma'an Governorate. The study population consisted from 124 teachers. The sample of the study consisted of 63 male and female teachers who were selected using simple random sampling technique. This sample was chosen because of the distribution of the schools on a wide geographical area and some of them are remote from the center of Ma'an Governorate making it difficult for the researchers to reach all the teachers in the study population.

\subsection{Data Collection Instrument}

The used data collection instrument was an observation sheet. The observation sheet was developed based on FIACS. In order to verify the validity of the used instrument, a panel of expert, which consisted from 10 faculty members at a university in Jordan, reviewed the observation sheet. The faculty members were specialized in Arabic language, measurement and evaluation, and curriculum and instruction. Based on the reviewers' comments, the authors reviewed the observation sheet and made the necessary adjustments. The observations sheet was reviewed to fit the educational system in Jordan.

In order to verify the internal consistency of the data collection instrument, the instrument 
was applied on pilot study that consisted from a sample of 31 teachers from outside the study sample. Pearson correlation coefficient was computed between the score of each dimension of the verbal interaction and the total score of the scale. Table 2 shows the coefficients of correlation of the score of each dimension of the verbal interaction in the instrument and the total score of the scale

Table 2. The coefficients of correlation of the score each dimension of the verbal interaction in the instrument and the total score of the scale

\begin{tabular}{lll}
\hline & Dimension & Correlation coefficient \\
\hline 1 & Teacher Talk & $0.82^{*}$ \\
2 & Student Talk & $0.97^{*}$ \\
3 & Silence or confusion & $0.83^{*}$ \\
\hline
\end{tabular}

* Significant at $\alpha=0.01$.

Table 2 shows that the relationship between each dimension of verbal interaction and the overall measure is statistically significant at $(\alpha=0.01)$. Such significant relationships confirm that the scale has a high degree of internal consistency.

Pearson correlation coefficient was also computed between the score of each item in each dimension of verbal interaction and the total score of that dimension. The results showed that the examined relationships were statistically significant at $(\alpha=0.01)$. The correlation coefficient values ranged from 0.47 to 0.85 . Such values indicated high degree of internal consistency of the instrument.

In order to verify the reliability of the data collection instrument, the instrument was applied on pilot study that consisted from a sample of 31 teachers from outside the study sample. Cronbach's alpha coefficient was computed for data from the pilot study. The value of Cronbach's Alpha was 0.91. Furthermore, the reliability of the data collection instrument was verified using split- half method with Spearman-Brown formula; the value split-half reliability coefficient was (0.84). The values of the reliability coefficients indicated that the data collection instrument had a high degree of reliability, which assured the researchers to apply the instrument on the study sample.

\subsection{Procedure of the Study}

First, the necessary approvals have been obtained from the authorities to implement the study tool in the tenth grade classes at Ma'an Governorate. Then, the researchers reviewed the used observation instrument and the similar previous studies that used such instrument. After that, the researchers trained a number of experienced teachers to apply the observations sheet in classrooms. These teachers applied the observation sheet for 70 minutes of class time over two class meetings for each teacher who participated in the study.

The researchers answered all the trainees' questions related to the use of the observations sheet. The trainees were instructed to focus on the following aspects: 


\section{Macrothink

- The observer should sit in a place in the classroom where he/she can see all the students and their teacher at the same time. Then, the observer should record behavior of the teacher and students every 10 seconds. If more than one behavior occurs during this period, the observer should record the behavior in the observation sheet even if this behavior happened within less than the 10 seconds.

- The observer should observe the progress of the lesson during the first five minutes of the lesson before starting recording the behaviors of the teacher and students.

- The observer should record the behaviors of the teacher and students for 35 minutes.

- If the behavior of the teacher or students change completely and suddenly as a result of changing the nature of the classroom interaction between teacher's two types of influence: direct influence and indirect influence or students' constructive responses to students' destructive responses, the observer has to wait for a few seconds to determine the type of change and after that he/she can resume recording the behaviors of the teacher or students. Furthermore, if the observer observes patterns of behavior that were not written in the observation sheet, such as negative behavior from the teacher towards the learners or vice versa, or verbal physical, or psychological punishment; the observer should record such behaviors at the end of the observation sheet in the section of comments and other additions.

- The researchers adopted Tally marks in the form of a clustering five slash together to facilitate the subsequent collection and computing of frequencies and percentages of the verbal interaction patterns.

- After performing this procedure, the statistical analysis, necessary to extract the results, was performed.

\section{Results and Discussion}

5.1 The result of the first research question: What are the most common verbal interaction patterns among the Arabic language teachers of tenth grade according to the FIACS?

To answer the first question, percentages were computed for verbal interaction patterns. Table 3 shows percentages of the verbal interaction patterns and dimensions. 
Table 3. The percentages of the verbal interaction patterns and dimensions.

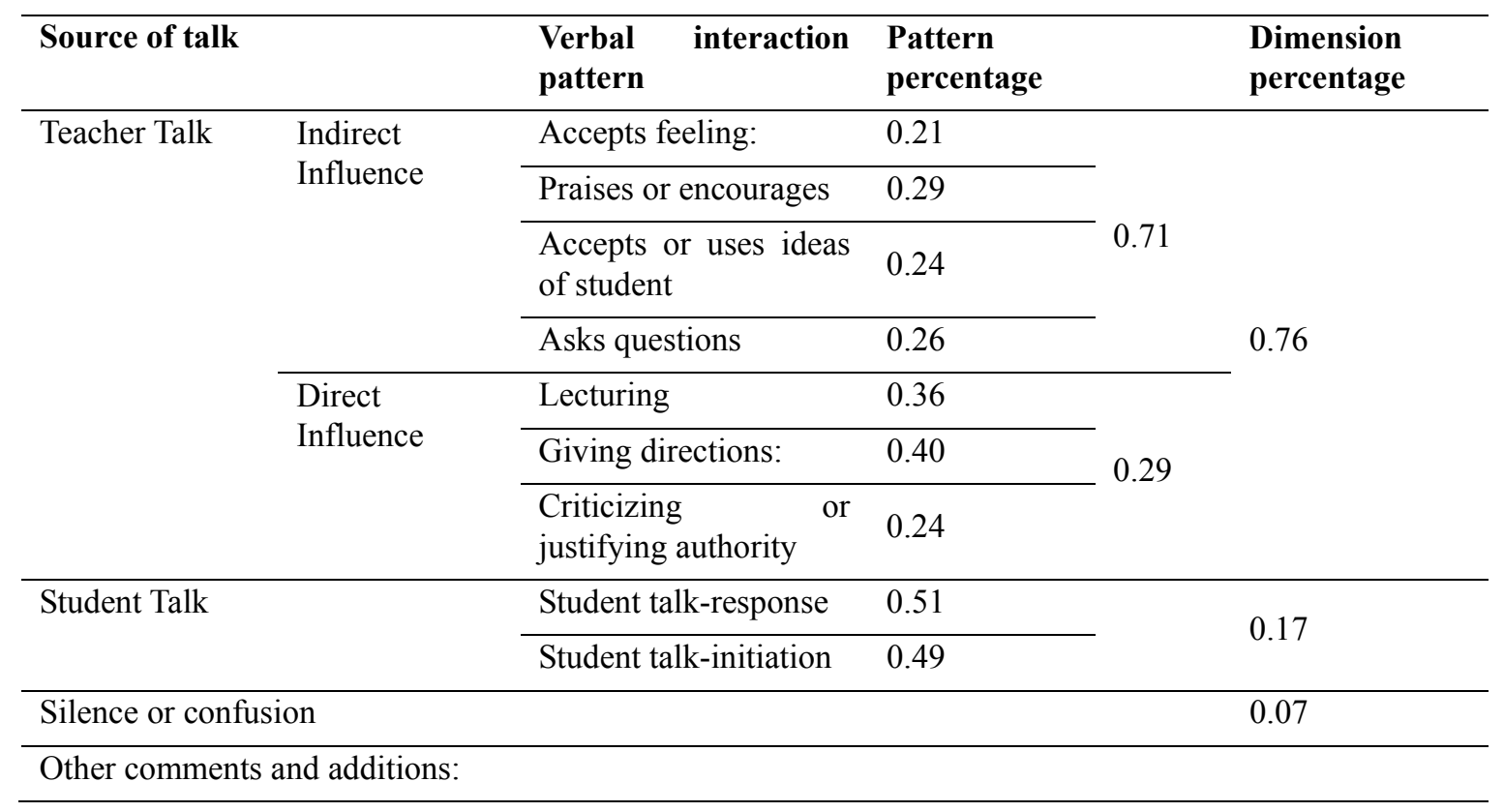

Table 3 shows the percentage of teacher and students talks in the Arabic language lesson. Teacher talk was dominant in most of the class time with an average of 76 per cent and student talk was less dominant with an average of 17 per cent, while silence or confusion accounted for 0.07 per cent of class time. The indirect influence component of teacher talk was dominant form of teacher talk with an average of 71 percent while direct influence component of teacher talk scored an average of 29 per cent. The category of direct influence component of teacher talk that scored the highest percentage was "Giving directions" that had a $40 \%$ rating. The category of indirect influence component of teacher talk that scored the highest percentage was "Praises or encourages" that had $29 \%$ rating. The findings aligned with the finding of similar research studies (Nurmasitah, 2010; Gorongo, 2013; Al-Amri, 2016).

The high percentage of teachers' talk compared to the percentage of students' talk may be explained by the fact that teachers in the Jordanian educational system were still acting as the controller of the educational activities and events in the classroom. The teachers followed educational methods that rely on giving directions and orders to students. In addition, the teachers followed direct educational methods that rely on explanation, indoctrination, and lectures. Such use of these educational methods is evident in the results where "Lecturing" accounted for $36 \%$ of direct influence component of teacher talk.

This result might also be attributed to students' reluctance to participate in the educational process during the lesson and their dependence on the teacher's information and explanations related lesson topics. Therefore, they acted as recipients of information rather than acting as an active participants and interlocutors in the classroom. 


\section{Macrothink}

International Journal of Learning and Development

ISSN 2164-4063 2017, Vol. 7, No. 4

5.2 The a result of the second research question: Are there statistically significant differences, at the level of $(\alpha=0.05)$, in the extent of teacher-student verbal interaction based on teachers'gender?

In order to answer the second research question, t-tests were conducted to examine the variations in the extent of teacher-student verbal interaction based on teachers' gender (Table 4).

Table 4. Results of t-tests and descriptive statistics for teacher-student verbal interaction based on teachers' gender

\begin{tabular}{llllllll}
\hline & Gender & Number & Average & SD & Degree of freedom & $\mathrm{t}$ & Sig. \\
\hline Teacher talk & Male & 20 & 20.8 & 12.7 & \multirow{2}{*}{61} & \multirow{2}{*}{1.25} & 0.22 \\
& Female & 43 & 27.54 & 21.9 & & & \\
Student talk & Male & 20 & 4.6 & 3.4 & 61 & 1.07 & 0.29 \\
& Female & 43 & 6.00 & 5.6 & & & \\
\hline
\end{tabular}

Table 4 shows that there were no statistically significant differences in the extent of teacher-student verbal interaction in either teacher talk or students talk dimensions according to teachers' gender. This result is consistent with the results of Al-Hadi's (2009) study.

Such result can be explained by the possible similarity between the educational methods used by both, female and male teachers. The female and male teachers interact with their students in slimier ways and they allow their students to participate during teaching process in slimier ways. This result may have emerged since the students of the female and male teachers had similar nature of interaction with their teachers during the lesson.

5.3 The a result of the third research question: Are there statistically significant differences, at the level of $(\alpha=0.05)$, in the extent of teacher-student verbal interaction based on teachers' academic degree?

In order to answer the third research question, regarding the variations in the extent of teacher-student verbal interaction based on teachers' academic degree, Analysis of variance (ANOVA) was conducted (Table 5). 
Table 5. One-Way ANOVA- teachers' degree of verbal interaction in two dimensions (i.e., teacher talk and student talk) based on their academic degree

\begin{tabular}{llllllll}
\hline Dimension & Groups & $\begin{array}{l}\text { Sum of } \\
\text { Squares }\end{array}$ & $\begin{array}{l}\text { Degree of } \\
\text { Freedom }\end{array}$ & $\begin{array}{l}\text { Mean } \\
\text { Square }\end{array}$ & F & Sig. & $\begin{array}{l}\text { Statistical } \\
\text { significance }\end{array}$ \\
\hline Teacher talk & $\begin{array}{l}\text { Between } \\
\text { groups }\end{array}$ & 1919.45 & 2 & 959.75 & & & \\
& $\begin{array}{l}\text { In groups } \\
\text { Overall }\end{array}$ & 21922.45 & 60 & 365.37 & 2.63 & 0.08 & Insignificant \\
\hline Student talk & $\begin{array}{l}\text { Between } \\
\text { groups }\end{array}$ & 62.13 & 2 & 31.06 & & & \\
& $\begin{array}{l}\text { In groups } \\
\text { Overall }\end{array}$ & 1501.53 & 60 & 25.03 & 1.24 & 0.29 & Insignificant \\
& 1563.66 & 62 & & & & \\
\hline
\end{tabular}

Table 5 shows that there were no statistically significant differences in the extent of teacher-student verbal interaction in either teacher talk or students talk dimensions according to teachers' academic degree.

This result may be explained by the nature of the teachers' academic qualifications. The university Arabic language programs that the teachers graduated from may have focused on theoretical information and ideas related to the field of the Arabic language. In Jordan, in different Arabic language university programs e.g., Bachelor, Diploma, and Master, there are scarcity in the courses that focus on teaching the future teachers and teachers the teaching methods that promote classroom interaction, classroom discussion and classroom participation.

5.4 The a result of the fourth research question: Are there statistically significant differences, at the level of $(\alpha=0.05)$, in the extent of teacher-student verbal interaction based on teachers' years of experience?

In order to answer the fourth research question, regarding the variations in the extent of teacher-student verbal interaction based on teachers' years of experience, Analysis of variance (ANOVA) was conducted (Table 6). 
Table 6. One-Way ANOVA- teachers' degree of verbal interaction in two dimensions (i.e., teacher talk and student talk) based on their years of experience

\begin{tabular}{|c|c|c|c|c|c|c|c|}
\hline Dimension & Groups & $\begin{array}{l}\text { Sum of } \\
\text { Squares }\end{array}$ & $\begin{array}{l}\text { Degree of } \\
\text { Freedom }\end{array}$ & $\begin{array}{l}\text { Mean } \\
\text { Square }\end{array}$ & $\mathbf{F}$ & Sig. & $\begin{array}{l}\text { Statistical } \\
\text { significance }\end{array}$ \\
\hline \multirow[t]{3}{*}{ Teacher talk } & $\begin{array}{l}\text { Between } \\
\text { groups }\end{array}$ & 2083.31 & 2 & 1041.65 & \multirow{3}{*}{2.87} & \multirow{3}{*}{0.06} & \multirow{3}{*}{ Insignifican } \\
\hline & In groups & 21758.63 & 60 & 362.64 & & & \\
\hline & Overall & 23841.94 & 62 & & & & \\
\hline \multirow[t]{3}{*}{ Student talk } & $\begin{array}{l}\text { Between } \\
\text { groups }\end{array}$ & 254.86 & 2 & 127.43 & \multirow{3}{*}{5.84} & \multirow{3}{*}{0.005} & \multirow{3}{*}{ Significant } \\
\hline & In groups & 1308.79 & 60 & 21.81 & & & \\
\hline & Overall & 1563.65 & 62 & & & & \\
\hline
\end{tabular}

Table 6 shows that there were statistically significant differences in the extent of teacher-student verbal interaction in students talk dimension according to teachers' years of experience. However, there were no statistically significant differences in the in the extent of teacher-student verbal interaction in teacher talk dimension according to teachers' years of experience. To determine the direction of the differences, A Scheffe post hoc test was conducted. Table 7 shows the results of the post-comparisons.

Table 7. Results of Scheffe post hoc test for the students talk scale of FIACS.

\begin{tabular}{lll}
\hline Years of Experience & Less than (5-10) years & More than 10 years \\
\hline$(1-5)$ & $*-4.43$ & -0.99 \\
\hline$(5-10)$ & 3.43 & \\
\hline
\end{tabular}

Table 7 shows that the teachers with 1-5 years of experience had a significant higher score in the student talk scale in comparison with the teachers with 5-10 years of experience. In the class of Arabic language of tenth grade, teachers with a low teaching experience allow their students to talk more than the teachers with a high teaching experience.

This result may be explained by the high enthusiasm level toward teaching profession by the teachers who were recently employed compared to the teachers with long years of teaching experience. In addition, new teachers are usually required to attend educational training courses in order to provide them with various and modern teaching methods. These training courses focus on teaching teachers the educational methods that allow students to be active practitioners in the classroom, encourage students to participate in discussion with their teachers, and encourage students to ask questions and express their opinions. The teacher's role in these teaching methods would be limited to be guider or facilitator of the educational process. New teachers' adoption of these methods may encourage their students to actively participate and to demonstrate positive interaction in educational process compared with those students who have been taught by more experienced teachers. Teachers with high 
number of years of experience did not show sufficient interest in students' active participation in the classroom. Teachers with high number of years of experience may feel boredom and weariness in relation to teaching profession. Therefore, the main interest of teachers with high number of years of experience would be delivering instruction and providing explanations regardless of the positive teacher-student verbal interaction and student-student verbal interaction.

\section{Conclusion and Recommendations}

The most common form of classroom verbal interaction in the Arabic language class for the tenth grade was teacher talk. There were no significant differences in extent and nature of classroom verbal interaction based on teachers' gender and academic degree. However, there that there were significant differences in extent and nature of classroom verbal interaction based on teacher' years of experience. In the light of the results of this study, the researchers recommended the following:

1- Decision makers and educational leaders should instruct and guide teachers to avoid controlling the classroom activities, to avoid using direct instruction, and to avoid issuing instructions and orders in the classroom.

2- Decision makers and educational leaders should instruct and guide teachers to pay attention to the role students in the classroom verbal interaction through providing students with classroom environment that promote discussion, participation and sharing opinions.

3- Decision makers, educational leaders, and teachers should work together to provide students with an appropriate educational environment, and provide a psychological environment that helps students to be active practitioners and initiative in the educational process.

4- There is a need to conduct more similar studies in other grades rather than tenth grade.

5- There is a need to conduct more similar studies in other subjects rather than Arabic language.

\section{References}

Adas, A. (1999). Educational Psychology: A Contemporary Perspective. Dar Al-Fikr for Publishing and Distribution, (2), Amman, Jordan.

Al-Amiri, M. (2016). Analysis of Verbal Interaction of Students of The Department of Social Studies in the Institute of Preparation and Training of Teachers During Service in Hadramout in light of Flanders System. Al-Andalus Journal of Humanities and Social Sciences. 13(12), 99-127.

Al-Badri, T. (2005). Management OF Classroom Verbal Interaction "Principles and Procedures". Dar Al Thaqafa for Publishing and Distribution: Amman, Jordan.

Al-Farra, I. (2004). Evaluation of Teaching Performance of the Teachers in the Basic Education Stage of Palestinian University Graduates, A Paper Presented at the Conference on 


\section{Macrothink}

International Journal of Learning and Development

ISSN 2164-4063 2017, Vol. 7, No. 4

Quality in Palestinian University Education: Ramallah, 2004, pp. 10 and 11.

Al-Hadi, O. (2009). Verbal Interaction patterns among teachers of primary education "field study sample schools Ouargla state," Master Degree Paper, Ouargla Province, Algeria.

Al-Khatibeh, M., Al-Sultani, A., \& Al-Tuwaisi, A.(2004). Classroom Verbal Interaction. Dar Al Shorouk for Publishing and Distribution: Amman.

Al-Sfasfh, A. (2005). Management oF Classroom and Verbal Interaction. Y azeed Center for Student Services: Amman, Jordan.

Amatari, V. O. (2015). The Instructional Process: A review of Flanders' Interaction Analysis in a Classroom Setting. International Journal of Secondary Education, 3(5), 43-49. https://doi.org/10.11648/j.ijsedu.20150305.11

Amidon, E. \& Flanders, N, (1963). The Role of the Teacher in the Classroom: A Manual for Understanding and Improving Teachers' Classroom Behavior. Minneapolis, Minnesota: Paul S. Amidon \& Associates, Inc., Arifaj, S. (2007). Contemporary Educational Administration, (3). Dar Al-Fikr: Cairo.

Goronga, P., (2013). The Nature and Quality of Classroom Verbal Interaction: Implications for primary school teachers in Zimbabwe. Academic Research International, 4(2), 431.

Ibrahim, A. (1987). Evaluation of Teaching Performance of Arabic Language Teachers Using Flanders Model for Verbal Interaction (FIAC). Journal of the Faculty of Education, Assiut. (5), 118-131.

Nurmasitah, S., (2010). A study of classroom interaction characteristics in a geography class conducted in English: The case at year ten of an immersion class in SMA N 2 Semarang (Doctoral dissertation, UNIVERSITAS DIPONEGORO).

Qatami, Y., \& Qatami, N. (2001). Teaching Psychology. Dar Al Shorouk: Amman, Jordan.

Sharma, S. (2016). A Study of Classroom Interaction Characteristics Using Flanders' Classroom Interaction Analysis In a Math Class of Rural And Urban Schools. Scholarly Research Journal for Humanities Science \& English Language, 3(15). 3770-3776.

Shubar, Kh., Jamil, A., \& Abu-Zeid, A. (2005). The Basics of Teaching. Dar Almnaheg for Publishing and Distribution: Amman, Jordan.

\section{Copyright Disclaimer}

Copyright for this article is retained by the author(s), with first publication rights granted to the journal.

This is an open-access article distributed under the terms and conditions of the Creative Commons Attribution license (http://creativecommons.org/licenses/by/4.0/). 